\title{
Uppfostran till självsvält? \\ Om yttre och inre kontroll av den unga flickans kropp och karaktär kring sekelskiftet 1900.
}

\author{
ANNA-KARIN LARSSON
}

\begin{abstract}
Yttre och inre kontroll av kropp och karaktär hos unga flickor tycks vara gemensamma levnadsvillkor för både de medeltida "heliga anorektikerna" och dagens självsvältande tonårsflickor. I uppfostringslitteratur från sekelskiftet 1900 framgår tydligt kravet på självkontroll hos unga flickor i samband med ätande, uppförande och kroppsideal. Men även den unga flickan tycks ha använt matvägran som ett sätt att uttrycka ett behov av inre kontroll och protest mot den begränsade kvinnorollen.
\end{abstract}

\begin{abstract}
„Unga damer, som besväras af korpulens eller frukta för godt hull och stark rodnad på kinderna, företaga ej sällan i afsigt att erhålla en blekare och intressantare hy att t.ex. dricka ätticka och förtära en mängd sura ämnen" (Uhrström 1881, s.3).
\end{abstract}

Under sent 1800-tal uppstod ett nytt kvinnligtskönhetsideal inom samhälletsövreskikt. För att vara attraktiva skulle flickorna vara smala, bräckliga och bleka. Det för tiden förhärskande kvinnoidealet uppmanade för-

Fil.mag. Anna-Karin Larsson är doktorand i historia vid Örebro universitet. Hon arbetar med en avhandling om ätstörningar i ett historiskt perspektiv där flickors uppfostran, ideal och sjukdomar är centrala undersökningsområden. Avhandlingen beräknas vara klar 2004. äldrarna att hålla sina flickor på svältkost och för den bleka hyns skull fordrades ett liv inomhus. De unga kvinnorna försökte enligt läkaren Wilhelm Uhrström bli av med oönskat hull och erhålla en eftersträvansvärd blekhet genom att dricka ättika och intaga sura ämnen. Den smala kroppen hos både män och kvinnor signalerade hög social status, ömtålighet och skönhet. Tydligt framträder idealet i romantiseringen av den smala, bleka och tuberkulösa kroppen i både litteraturen och poesin. Poeter som Shelley och Byron ratade maten för den smala och svaga kroppens skull och de, liksom den övriga kulturella eliten, hyllade det tuberkulösa utseendet. Tuberkulos ansågs vara en sjukdom som främst drabbade emotionella och kreativa personer. Den medföljande svagheten och sjukligheten betrakta-

Socialvetenskaplig tidskrift nr 1-2 • 2001 
des som förhöjare av kreativiteten (Se bl.a. Vandereycken \& van Deth 1990).

I dag står smalheten för andra ideal nämligen god moral, intelligens och framåtanda. Att vara smal är att vara frisk, inte längre sjuk. Att ha tid, råd och kunskaper att ta hand om sin kropp tyder på disciplin, ambition och framgång. Dess motsats fetma, står för ointelligens, dålig moral och slapphet. Den feta kroppen anses till och med vara skamlig. Vårt komplicerade förhållande till kroppen har lett till att kvinnor, men även män, under lång tid har sett sig tvungna att omskapa och förändra dess ursprungliga form. Kroppsidealet säger något om de värderingar och föreställningar som präglar dess samtid. ${ }^{1}$ Sjukdomarna eller de kroppsliga uttrycken kan ses som en överdrift av våra kollektiva ideal. I olika tider och kulturer tycks skiftande ideala bilder av kroppen ha skapats och därmed har också de fel och brister som måste elimineras utpekats.

Det finns i dagens samhälle en allmänt spridd uppfattning om att ätstörningar och sjukdomar som anorexia nervosa och bulimia nervosa till stor del orsakas av det magra kroppsidealet som förmedlas via media, reklam och mode. I denna artikel ska jag sätta in dagens ätstörningsproblem i ett längre historiskt perspektiv med syftet att försöka nyansera bilden något. Ett smalt kroppsideal för kvinnor har inom vissa kulturer varit rådande från den viktorianska eran till i dag, men vad är det egentligen idealet står för?

1 Se bl.a. Johannisson, Karin (1997) Kroppens tunna skal, med essäer om kroppens historia där kroppen som spelplan, språk och symbol för kulturen analyseras.
Genom att studera flickors uppfostran kring sekelskiftet 1900 hoppas jag finna ledtrådar till gåtan vad det är flickor och unga kvinnor uttrycker samt varför de uttrycker detta med hjälp av kroppen.

\section{Teorier om självsvält}

Självsvält som symtom är en flerhundraårig företeelse. Sjukdomen anorexia nervosa däremot är en sjukdomskonstruktion sedan 1870-talet. ${ }^{2}$ Att svälta sin kropp har varit ett sätt varigenom främst flickor och kvinnor har försökt uppnå inte bara den perfekta kroppen utan också den rätta karaktären. Vissa forskare menar att självsvält inte kan jämställas som samma uttryck över tid eftersom det mer eller mindre medvetna valet att svälta sin kropp har berott på så olika orsaker. Den symboliska innebörden av självsvält har förändrats. Den unga kvinnan som svalt under medeltiden uttryckte inte ett begär efter en smal och en av samtiden betraktad vacker kropp. Den smala kroppen har varit attraktiv för flickor framför allt från samhällets övre skikt i flera

2 Ordet anorexi betyder aptitlöshet. Det används ibland synonymt med anorexia nervosa men symtomet bör skiljas från sjukdomen. Symtomen anorexi kan förekomma vid andra sjukdomar än anorexia nervosa, t.ex. vid tumörsjukdomar, infektioner eller depressioner. Anorexia nervosa är en diagnos och ett speciellt sjukdomstillstånd som bedöms utifrån ett antal uppställda kriterier. Ofta påpekas inom forskningen att anorexia nervosa är ett missvisande namn då tillståndet egentligen inte primärt handlar om aptitlöshet utan vägran eller oförmåga att äta. 
sekler, men innebörden av smalheten har förändrats. Syftet med självsvälten för den medeltida flickan eller kvinnan, var inte att uppnå ett skönhetsideal. Hon sökte andliga snarareän kroppsliga ideal. Den andliga renheten och närheten till Gud snarare än samhälleliga normer och skönhet var eftersträvansvärd. Den mest kända av dessa heliga anorektiker är Katarina av Siena som inte bara vägrade äta utan också späkte sin kropp. $^{3}$

Det finns också forskare som hävdar att svälten var en protest mot den underordnade och undanskymda roll kvinnor tvingades leva i. Möjligheterna för en kvinna att uttrycka sig och sin vilja under medeltiden var inte särskilt stor. Den amerikanska historikern Joan Jacobs Brumberg menar att kontrollen av aptiten har varit gemensam för dagens anorektiker och de medeltida självsvälterskorna. Förr var kontrollen länkad till kroppens drifter och tolkades som en andlig strävan efter renhet och andlighet. I dag skall kroppens drifter kuvas för att uppnå kroppslig skönhet. Den andliga renheten har ersatts av den kroppsliga skönhetens kontext (Brumberg 1988). Gemensamt för de medeltida helgonen och dagens anorektiska flickor är att de uttrycker något genom att svälta sin kropp. Innebörden i självsvälten tycks vara det primära och innebörden uttrycks med hjälp av kroppen.

Inte bara innebörden i svälten har förändrats utan också den samhälleliga synen på tillståndet självsvält. Den medeltida självsvälterskan ansågs utvald av Gud och

3 Katarina Benincasa (1347-1380) är för eftervärlden mest kända som det fastande helgonet Katarina av Siena. uppnådde helgonstatus. Någon gång under 1800-talet ersattes det religiösa paradigmet av ett medicinskt och den själsvältande kvinnan uppfattades nu som en patient. Läkarna började intressera sig för hur de svältande flickorna som påstod sig leva på Guds andliga näring kunde överleva utan mat och i vissa fall även utan dryck. Var det helt enkelt en bluff från flickornas sida och ett sätt att söka uppmärksamhet? Det finns flera fall dokumenterade där svältande eller fastande flickor har undersökts, ifrågasatts och i vissa fall avslöjats för begrägeri då det visat sig att de gömt mat i sängen och ätit i smyg (Johannisson 1997). Den tidiga behandlingen av anorexia nervosa och ätstörningar utgick från medicinska förklaringsmodeller. Manliga läkare förklarade och diagnosticerade kvinnliga patienter som vägrade eller inte kundeäta utifrån kvinnans biologi och instabila psyke. De sökte först och främst efter förklaringar inom det medicinska paradigmet men ifrågasatte även de kulturella och sociala förhållandena i vilka kvinnorna och flickorna levde. En felaktig men förmodligen vanlig uppfostran inom familjer i samhällets övre skikt, kost och miljö ansågs kunna ligga bakom vissa fall av nervösa uttryck och sjukdomar som bleksot eller kloros. ${ }^{4}$ "Nervös är ett uttryck, som

4 Hysteri var en sjukdom som främst förekom hos unga flickor och ansågs bero på dålig uppfostran, sorger och bekymmer. Diagnosen ställdes främst mellan åren 1870 och 1915. Den närliggande sjukdomen bleksot (äv.kloros) förkom under samma år och liksom hysteri främst bland unga flickor. Orsakerna bedömdes även de bero på brister i uppfostran, dåliga hygieniska föhållanden, brist på frisk luft och omoraliskt beteende. Symtomen ansågs vara illamående, blek, nästan grönaktig hy, yrsel och aptitlöshet. 
man ofta får höra. Det är nästan modernt att vara nervös, alldeles som om ett ömtåligt och retligt nervsystem skulle höra till den goda tonen och tillkännagifva 'finı smak, och ,finı uppfostran«(Uhrström 1881).

Först under det förra seklet börjadeläkarvetenskapen på allvar sluta sig till uppfattningen att mentala sjukdomar och psykologiska tillstånd är relaterade till vår kultur och att samhälleliga faktorer spelar en roll i skapandet av dessa. Den australiensiska psykologen Julie Hepworth (1999) menar att definitionen av anorexia nervosa är socialt konstruerad och har uppstått i en specifik historisk kontext. Förklaringarna till tillståndet stämmer överens med den i tiden dominerande diskursen kring vetenskapen, medicinen och kvinnan. Behandlingen av patienterna, synen på flickorna och orsakerna till sjukdomen bestäms av den samhälleliga kontext i vilken företeelsen tolkas. Vad samtiden definierar som sjukdom och som symtom förändras över tid och inom olika kulturer. Medicinen har, bör vi påminna oss, genom historien haft tolkningsföreträde och "skapat" och definierat flera sjukdomar samt definierat sjukdomsbilderna. Ätstörningar har åtminstone fram till i dag, varit en sjukdom som drabbat vita flickor ur medelklassen. Nu börjar mönstret rubbas eftersom alltfler fall av anorexia nervosa dyker upp i icke-västerländska kulturer bland flickor och pojkar från skilda sociala och ekonomiska förhållanden. En förklaring till denna utveckling kan vara att det inte bör ses som ett specifikt västerländskt problem, utan snarare ett modernitets- och välfärdsproblem. Aktuell forskning visar att symtomen för anorexia nervosa också har varierat mellan kulturer. Ända sedan sjukdomens "upptäckare», den brittiske läkaren William Gull och hans franske kollega Charles Lasègue, definierade sjukdomsbilden har viktfobi, rädsla för fetma och den eftersträvansvärda smalheten varit karaktäristiska kännetecken hos den drabbade flickan. I Asien däremot saknas t.ex. fetmafobin hos de ännu så länge relativt få ätstörningspatienterna (Lee 1996). Detta förhållande visar på att inte bara de olika formerna av självsvält har förändrats. Den accepterade sjukdomsbilden för anorexia nervosa kan också ta olika former i olika kulturer beroende på vilken symbolisk innebörd begreppen kropp, kön och mat tilldelas.

\section{Feministiska, sociala och kulturella teorier om självsvält}

På 1970-taletbörjade den traditionella medicinska förklaringen till anorexia nervosa eller den "självvalda" aptitlösheten ifrågasättas av forskare och skribenter som utgick från sociala, kulturella och feministiska teorier. Förespråkare för dessa teorier menade att den medicinska förklaringsmodellen förringade problemet med kvinnors ätstörningar. Främst de feministiska forskarna hävdade att ätstörningar till stor del beror på det samhälleliga förtrycket av kvinnor. Själsvälten sågs som en protest mot underordningen. Dessa forskare menade således att självsvälten, då flickan tog kontroll över sin egen kropp och sitt eget matintag, var ett desperat försök för att ta kontroll över sitt eget liv.

Förtrycket av kvinnan, menade de feministiska forskarna, förmedlas via medveten och omedveten uppfostran av flickorna bl.a. genom på vilket sätt förhållandet till mat 
framställs. Dessa förhållanden till mat i form av skuldkänslor, tröstätande och förnekande av aptit och näringsbehov, manifesteras i yttersta fall i form avätstörningar (Hepworth 1999). De feministiska forskarna har också hävdat att självsvälten kan vara ett ytterst konkret sätt att försöka hejda både den fysiska och psykiska utvecklingen mot vuxenblivandet och den därmed konstruerade (och begränsande) kvinnorollen. Psykologiska teorier om internalisering försöker också förklara varför flickorna internaliserar det destruktiva förhållandet till maten och ätandet liksom det ohälsosamma och förgörande kroppsidealet.

De feministiska, sociala och kulturella teorierna kring ätstörningar har bidragit till att förändra förståelsen för det problematiska förhållandet mellan kvinnor och mat. Det är viktigt att komma i håg att dessa teorier är liksom de tidiga medicinska förklaringsmodellerna uppkomna i sin tids samhälleliga kontext. Det är inte nödvändigtvis så att de förra teorierna som uppstod inom det religiösa eller inom det medicinska paradigmet är helt oanvändbara och saknar förklaringsvärde i dag. De sociala, kulturella och feministiska teorierna snarare kompletterar de förra och kastar ett nytt ljus över problemet. Möjligheterna har öppnats för nya frågor att ställas.

De flesta forskare betonar i dag längtan efter kontroll som ett av de viktigaste symtomet inom sjukdomsbilden för anorexia nervosa (Prestjan 2000). Anorexia nervosa och självsvält handlar alltså inte om förlust av aptit utan om kontroll av den. Det tycks vara ett inre tvång att uppnå kontroll över kroppens drifter, t.ex. hunger, sexualitet och känslor, som är gemensamt för flickor och kvinnor som vägrar mat och som svälter sina kroppar. Fixeringen vid mat kan bli ett tvång. Den självvalda kontrollen kan fungera som ett motstånd mot den utifrån kommande kontrollen på individ-(dvs. inom familjen) eller samhällsnivå. Regleringen av kroppens drifter visar sig i kontroll av vikten och sitt matintag.

\section{Från ett individuellt till ett kollektivt problem}

En utgångspunktär att försöka studera självsvält och sjukdomar som anorexia nervosa utifrån ett samhälleligt och kulturellt perspektiv där orsakerna inte ligger hos individen utan snarare i det samhälle vi har skapat. Genom att anlägga ett relativistiskt perspektiv uppstår möjligheten att undersöka gemensamma nämnare för flickor och kvinnor som svälter och har svultit sina kroppar. Det är i såfall inte symtomen självsvält som förändrats utan endast tolkningen av den. De medeltida "heliga anorektikerna» går alltså att jämföra med dagens tonårsflickor som svälter sig. Motiv och orsaker blir på så sätt jämförbara trots att innebörden i själsvälten har förändrats. Detta innebär inte att de medeltida svältande helgonen kan tilldelas diagnosen anorexia nervosa eftersom detta är en sjukdom som är skapad och definierad i en annan tid och kultur. Ett exempel på relativistisk forskning är Cajsa Lindholms artikel »Törnekrona- nu eller i evigheten? «(1991) Lindholm söker efter allmängiltiga konstanter i självsvälten från den medeltida Katarina av Siena till dagens tonårsflickor. Det gemensamma för uttrycken är kontrollen hävdar Lindholm. Anorektikern 
söker liksom Katarina av Siena och andra svältande kvinnor genom historien kontroll; de söker kontroll över sin egen livssituation och över sitt eget liv.

Den nutida anorektiska flickan blir en i raden av alla flickor och kvinnor som använt matens symboliska språk för att ta kontroll över sitt liv. Kontrollaspekten återfinns inte bara i forskningens utifrånperspektiv. En önskan att uppnå kontroll över tillvaron, kroppen och drifterna återkommer ständigt som motiv i olika källor, från uppfostringslitteratur, skönlitteratur, memoarer, dagböcker och aktuell forskning. Ett exempel är de s.k. självberättelserna i vilka f.d. anorektiker berättar sin historia. Temat kontroll återkommer ständigt i dessa (se t.ex. Wallgren 1995). Den norska antropologen Jorun Solheim (1998) menar att den självvalda svälten handlar om att stänga kroppens öppningar och upprätta gränser mot det utifrån kommande orena, dvs. mat, sexualitet och andra människor. "Anoreksi handler dypest sett om grenser, grenser som icke finnes, og som derfor må settes med dødelig alvor.u Två mycket starka symboliska sfärer i detta sammanhang är mat och hygien där det tidigare handlar om att ta in, och det senare om att stänga ute.

Det relativistiska perspektivet öppnar således möjligheten att studera fenomenet självsvält över en längre tidsperiod. Trots dess skilda innebörder tycks det finnas en gemensam nämnare till de olika formerna av självsvält. De kroppsliga idealen har varierat över tid och är i fråga om en gemensam nämnare för orsaken till självsvält, inte intressant. Det tycks snarare vara behovet att uppnå kontroll eller att upprätta gränser som kan ligga bakom de olika uttrycken mat- vägran, självsvält, ätstörningar och anorexia nervosa. Kroppen är ett verktyg samt en spelplan på vilken behoven synliggörs.

\section{Självkontroll i uppfostran}

Det finns en rad angreppssätt att använda för att komma åt den kulturella och historiska bakgrunden till ätstörningar och flickors utvecklande av ätstörningar. En central utgångspunkt är att söka efter värden och normer i den västerländska borgerliga kulturen som skulle kunna förklara varför flickor och unga kvinnor har drabbats och fortfarande drabbas av anorexia nervosa, ätstörningar och varför de svälter sina kroppar. Det är viktigt att förstå varför faktorer som mat, kropp och kön är och har varit så laddade och fulla av symbolik, och varför flickorna valde och fortfarande väljer att uttrycka sig genom och med hjälp av dessa symboler.

Att undersöka vilken roll självkontroll som fenomen i flickuppfostran har spelat är ett sätt att närma sig detta problem. I Body Politics hävdar Nancy Henley att icke-verbal kommunikation som kroppsrörelser, gester, former och förhållningssätt i det dagliga livet är en grundläggande kraft som bidrar till att maktförhållanden och kontroll vidmakthålls och förstärks (Henley 1977). Henley menar att icke-verbal kontroll som syftar till att påverka eller tvinga individer att uppträda på ett visst sätt, utgör en särskilt starkt inflytande på kvinnors beteende eftersom kvinnor ofta är utsatta för kontroll av den här typen. Kontrollen utövas på flera nivåer; från kontroll av individer till kontroll av grupper eller samhällen, från diskret till 
stark och synlig kontroll samt kontroll med mer eller mindre inslag av tvång och hot. På grundläggande nivå finns den internaliserade kontrollen, enligt Henley. Denna innebär att individer genom socialisationen blir påverkade att tänka och på ett visst sätt om sig själva och sin plats i hierarkin. Det enklaste sättet att få oss från att utmana de etablerade maktstrukturerna är genom att få oss att kontrollera oss själva.

Utöver den internaliserade kontrollen befästs makten genom omgivningens strukturering och tillgänglighet, icke-verbal kommunikation, verbal kommunikation och fysiska sanktioner. Om individen inte hindrar sig själv finns oftast andra personer som mer eller mindre uttalat gör individen medveten om begränsningar, faror och möjligheter. Om den diskreta kontrollen är overksam kan personen eller gruppen med makt hindra individen genom psykiska eller fysiska bestraffningar. En viktig del av kontrollen av flickor består också av hur pass tillgänglig omgivningen är rent fysiskt. Vissa platser har för kvinnor och flickor ansetts olämpliga och till vissa poster som universiteten, riksdagen och andra maktfulla inrättningar vägrades kvinnor länge tillträde. Kroppsligt har kvinnor och flickor begränsats genom exempelvis moden som snörningar och korsetter, höga klackar och korta kjolar. Än i dag gör modet oss orörliga och stela men för hundra år sedan kunde en snörd kvinna med stela och oformligt sydda klänningar varken andas eller röra sig.

Utifrån Henleys teoretiska resonemang om utövningen av kontroll på olika nivåer, kan det vara intressant att studera två aspekter av flickors uppfostran till självkontroll; dels idealen och normerna för flickor både vad gäller kroppen, karaktären och förhållandet till mat, dels praxis i fråga om hur och vad flickor åt samt hur de behandlade sin kropp. Det faktum att mat har använts av föräldrarna som medel för att utöva kontroll eller utdela straff är också viktigt i sammanhanget eftersom det förmodligen har bidragit till att skapa flickornas problematiska förhållande till mat. Hur kan man förklara att flickor tvingades leva på svältkost för att föräldrarna ville att de skulle uppnå ett kroppsideal och att flickorna i sin tur valde att svälta för att uttrycka ett missnöje, en protest eller för att upprätta gränser? Denna paradox är naturligtvis svår att förstå och reda ut, men med hjälp av Henleys begrepp om internaliserad kontroll och icke-varbal kommunikation hoppas jag nå en förståelse av problematiken.

Genom att studera flickuppfostran i början av 1900-talet kan man söka de historiska rötterna till dagens ätstörningar och sjukdomar som anorexia nervosa. De historiska rötterna kan och bör sökas och förhoppningsvis återfinnas inom områdena mat, kropp och kultur samt studeras i ett genusperspektiv eftersomätstörningar först och främst måste ses som ett kvinnoproblem. En historisk studie kan belysa den innebörd och mening i mat och ätande som präglar och har präglat vår kultur sedan 1800-talet.Smalhetsidealet har förmodligen en koppling till matkulturen liksom valet att använda mat och ätande som både ett inre och yttre kontrollmedel. I en kultur med dålig tillgång på mat finns inte ätstörningar i vår mening. Det kan dock finnas ideal som upphöjer asketism och matvägran men ätstörningar som kan relateras till ett kroppsideal tycks vara unikt för den 
västerländska kulturen från 1800-talet och framåt. En sjukdom som anorexia nervosa kräver en viss levnadsstandard för att ha någon mening. I situationer där föda är en bristvara och i kulturer där maten inte ses som ett njutningsmedel förlorar matvägran sitt symboliska värde.

Förhållandet till mat och innebörden i mat och ätande utgör en viktig ledtråd till flickors störda förhållande till ätande som i värsta fall kan utvecklas till anorexia nervosa. Kopplingen mellan vissa födoämnen och deras framkallande av diverse åkommor eller själsproblem diskuterades inom den samtida läkarvetenskapen redan kring förra sekelskiftet. Flickor som i dag förmodligen skulle bedömas ha ätstörningar förmanades att inte äta de födoämnen som antogs framkalla nervositet eller nervsvaghet. Framför allt animaliska och smakrika födoämnen ansågs reta magen och inte bara framkalla nervositet utan också försvaga kroppen. Läkare varnade för både skinka och kryddor samt "Äggen [som] duga därnäst alldeles icke för barnorganismen, de hjälpa endast till att skrufva upp dess nervositet ännu mera. ${ }^{5}$ Värst av allt för den lilla kroppen och själen var dock den utbredda vanan att ge barnen kaffe: „Den, som vill ha olyckliga barn, som äro behäftade med danssjuka, engelska sjukan, nervsvaghet och en mängd andra lidanden och krämpor, honom råder jag till att riktigt flitigt gifva sina barn indiskt kaffe. Han når sina mål säkert och hastigt! " 6

5 Kneipp, Sebastian (1894), Barnavård i friska och sjuka dagar. Se bihang "Om nervsvagheten" s. 197.

6 Kneipp (1894), s.192.
En intressant forskningsuppgift är att undersöka om barn fostras att förhålla sig till mat på olika sätt utifrån sitt kön. Om det går att finna tecken på att flickor och pojkar i praktiken och teorin har uppfostrat olika i fråga om mat och ätande, kanske man kan börja att söka förklaringen till flickors problematiska förhållande till inte bara maten och ätandet utan även kroppen och karaktären. Källor till denna forskningsuppgift skulle främst kunna vara uppfostringslitteratur samt hälsolitteratur och föreskrifter kring mat, hälsa och diet.

\section{Att kontrollera eller kontrolleras}

Den borgerliga familjen skulle kunna vara en lämplig utgångspunkt då det gäller att studera syftet med och moment i barnens och främst flickornas uppfostran. Kring sekelskiftet 1900 bestod den borgerliga familjen av tre huvudkaraktärer: den familjeförsörjande fadern, den ömma modern som stod för uppfostring och familjehushållning, samt barnet som nu sågs som en viktig resurs. Med hjälp av barnet skulle familjen kunna utöka och vidareförmedla sina resurser och tillgångar. En vacker flicka med de rätta inre och yttre kvaliteterna sågs som en stor tillgång då hon kunde förbättra familjens status och kapital genom det rätta äktenskapet. En missanpassad flicka kunde å andra sidan vara en stor belastning. Dåäktenskapsutsikterna var små eller inga alls, kunde flickan och hennes familj vänta sig att hon sällade sig till de ogifta kvinnornas växande skara. De yttre och inre kraven på flickorna tycks ha varit stora. En av de få manliga föresprå- 
karna för de kvinnliga emancipationssträvandena,stockholmsläkaren Fredrik August Cederschiöld, gav i flera artiklar uttryck för sina erfarenheter av hur den ur hans synvinkel felaktiga uppfostran gick till i de svenska medelklasshemmen:

Såsom förhållandena nu äro, anses verkligen den ogifta kvinnan ej äga synnerligt värde, vartill orsaken, utom de onaturliga band, som trycka henne, även kan sökas däruti, att kvinnans hela uppfostran går ut på, att hava slutat själens och hjärtats bildning till den tid, då flickans fysiska utveckling är fulländad, för att sedan blott vänta på den stund, då hon får stamma sitt "ja» till friarens böner. ${ }^{7}$

Kontrollen från föräldrarna var naturligtvis sträng och flickan uppfostrades till att den inre kontrollen var viktig och betydande. Självkontrollen var den yppersta dygden men samtidigt kunde den inre kontrollen ta sig uttryck som en protest mot föräldrarnas och omgivningens hårda krav. Pressen och kraven på flickan var stora och svåra att leva upp till. Kanske kan man säga att flickan i det viktorianska samhället tog kontrollen över sitt eget liv och sin egen kropp på ett sätt som liknar det de anorektiska flickorna gör i dag. För att söka spåren efter kontrollen av flickan, har jag valt att studera hur uppfostrare/pedagoger och läkare i artiklar och böcker har framställt flickan samt den ideala uppfostran för flickor.

7 Cederschiöld, F A (1852) Ett ord till Ömsinta Mödrar om Qvinnans Uppfostran, Sthlm s. 61-63.

\section{Yttre kontroll av kropp och karaktär}

Att använda maten och ätandet för att ta kontroll över sitt liv eller över sitt barns liv, är inget nytt påfund i det sena 1900-talet. Även om sjukdomen anorexia nervosa blommade upp från 1970-talet och framåt, ser det ut som om grunden för denna funnits i det traditionella sättet att se på flickor och kvinnor i relation till mat och ätande. "A woman should never be seen eating", skrev Lord Byron på 1800-talet och sammanfattade den viktorianska synen på kvinnor, mat och ätande. ${ }^{8}$ Hur uppfostrades barnen och då främst flickorna att förhålla sig till maten ochätandet? Självkontrollen var ett centralt tema i den borgerliga flickuppfostran kring sekelskiftet 1900. Förväntades flickor och kvinnor inte äta offentligt liksom Lord Byron uttryckte i citatet ovan? Förmedlades då inte en syn på maten och ätandet som något skamligt?

Bantandet och kontrollen av matintaget var regel snarare än undantag bland de borgerliga flickorna och kvinnorna. Brumberg (1988) hävdar att inom det borgerliga samhället var regleringen av aptiten en viktig del av den kvinnliga identiteten. Parallellerna

8 Det fullständiga uttalandet av Byron lyder: $» A$ woman should never be seen eating or drinking, unless it be lobster salad and champagne, the only trulyfeminine and becoming viands. «Lord Byron kritiserades av läkare i sin samtid eftersom han sades inspirerar och påverka unga flickor att svälta sina kroppar genom att romantisera den utmärglade kroppen. Byron hade själv ett komplicerade förhållande till sin kropp och sitt ätande. Han praktiserade självsvält i syfte att hålla sitt sinne rent och fruktade att förlora sin kreativitet om han tillät sig äta animaliska produkter eller fett.

Socialvetenskaplig tidskrift nr 1-2 • 2001 
med dagens kvinnliga förhållande till mat och ätande är tydliga. Regleringen av aptiten verkar hänga samman med det viktorianska samhällets sätt att se på förhållandet mellan kvinnans aptit och hennes sexualitet. En intensiv aptit på mat tydde på en lika intensiv aptit på sex. Den mest laddade födan var kött. Symbolvärdet låg i relationen till det syndiga, kroppsliga köttet och dess lustar. Flickor och kvinnor som gärna åt kött och i vad samtiden skulle ha definierat som överflöd, betraktades som galna och nymfomana. En väluppfostrad ung kvinna avstod alltid köttet vid måltiden (Nasser 1997).

Exemplen på hur flickor uppfostrades i praktiken är många. Den samhälleliga norm som borgarflickorna skulle passa in i var sträng och krävande. Under första hälften av 1800-talet utsattes Fredrika Bremer för en mycket sträng uppfostran. Hennes mor önskade en perfekt borgerlig flicka: smal, ömtålig, bildad och kuvad. Karin Johannisson menar att den yttre kontrollen från föräldrarnas sida inte skall underskattas. Skönhet utifrån de för tiden efterfrågade idealen var en flickas största tillgång på äktenskapsmarknaden och varje förälders största skräck var att få en stor och grov flicka (Johannisson 1994). Enligt Fredrika Bremers syster Charlotte var fru Bremers oro över att få döttrar som växte upp till ıstarka, långa och tjocka fruntimmeru så stor att Fredrika och hennes syster hölls på svältkost. Flickorna fick endast titta på sina föräldrars överdådiga maträtter, och själva äta knäckebröd och dricka vatten. „Voro vi än aldrig så hungriga, vilket vareviga dag inträffade, så vågade vi icke begära något att äta.ı ${ }^{9}$ Flickorna här-

9 Bremer (1868). dades och disciplinerades också genom att frysa i tunna klänningar i det vinterkalla hemmet, genom att ständigt påminnas om vikten av rätt utseende och genom att lära sig konsten att uppföra sig och röra sig på det korrekta sättet. ${ }^{10}$

Den flickkropp som inte passade in i den ideala mallen måste anpassas med kost och korsett. Faktum är att läkare varnade för det hälsovådliga kvinnomodet med hårda snörningar och tunga kjolar. Skrifter om hur den kvinnliga klädseln borde se ut och utformas skrevs och föreningar engagerades för att utarbeta och sy upp en ny dräkt som skulle "uppfylla behofvet af prydlighet, sundhet och ändamålsenlighet. ." ${ }^{11}$ Allt detta tyder på att bruket av korsetter och obekväma och orörliga klänningar var utbrett bland flickor och unga kvinnor. ${ }^{12}$

Den moderna uppfostran har sina rötter i den borgerliga 1800-talsideologin. Den inre disciplinen blev viktig då yttre straff inte längre kunde motiveras. Jonas Frykman och Orvar Löfgren (1979) visar på självkontrollens betydelse i barnens uppfostran i undersökningen av förändringen i det svenska samhället som skapade den kultiverade, kontrollerade och disciplinerade borgaren. Redan från späd ålder skulle barnen härdas. Ett

10 Ibid.

11 Winge, H \& Wallis, C (1885) Reformdrägten. En bok för quinnor skrifven af quinnor, $\mathrm{s}$.VII.

12 Se bl.a. Seved Ribbing (1899) som i Våra barns fostran och vård, kritiserar bruket och ställer upp hälsolärans viktigaste krav på förändring i kvinnoklädseln: 1:0 Att snörlifvet, samt alla kriing lifvet àtdragande kjortelband och linningar afskaffas. 2:0 Att kjortlarnestyngd minskas och att de uppbäras af axlarna, icke af höfterna. 
barn måste lära sig att bekämpa de onda sidorna hos sig själv. Dåliga sidor och svagheter måste bekämpas. Fördelarna med härdning av barnen understryks även i uppfostringslitteraturen. Vattenläkaren och kyrkoherden Sebastian Kneipp beklagade sig över den dåligt fostrade ungdomen som förslappade och försvagade av föräldrarnas felaktiga fostran och klemande utvecklade sjukdomar och nervositet. „Huru skall man hjälpa detta? Endast genom arbete, härdning och god föda kunna nervositetens offer botas och stärkas..."1 ${ }^{13}$ Rådet till det nervösa barnets mor löd; „Låt dessutom barnet, sedan det gått till sängs, dagligen stiga upp ur denna och taga ett bad i kallt vatten " ${ }^{14}$

Ett sätt att få barnen att utveckla sin självkontroll av sina inre drifter var genom att hjälpa det att uppnå en regelbundenhet i sina vanor. I När barnet fick en kropp skriver Kajsa Ohrlander(1987)att måltiden blev ett viktigt instrument varigenom barnen skulle lära sig vikten av kontroll och regelbundenhet. De naturliga känslorna av hunger och tröst skulle förtryckas. Vad som skulle ätas, hur och när, skulle helt bestämmas av modern. Om mat skulle det inte förhandlas eller klemas. I uppfostringsskriften Moralisk fostran från 1925, uppmanas föräldrarna att utveckla barnets självbehärskning med hjälp av regelbundna måltider: „Får ett barn såsom alla barn alltid borde ha, mat på bestämda tider, så infinner sig också hungern till dessa tider... ${ }^{15}$

13 Kneipp (1894), s. 202.

14 Kneipp (1894), s.199f.

15 Hildinger, Alf (1925), Moralisk fostran. En bok för föräldrar och andra ungdomens fostrare. Sthlm Bokförlaget Natur och Kultur. s.84.

\section{Inre kontroll av kropp och karaktär}

I vilka syften har flickorna tagit kontroll över sitt ätande och varför har de vägrat äta? Brumberg menar att skillnaden mellan flickors uppväxt i den viktorianska eran och i dag är att den tidigare fokuseringen på karaktären har ersatts av fokusering på kroppen och ytan. Karaktären skulle liksom kroppen skall i dag, byggas med hjälp av betoning på självkontroll. Skillnaden är att en ung flicka i dag försöker förbättra sitt yttre för att bli mer populär och omtyckt av omgivningen, medan en flicka för hundra år sedan snarare skulle bry sig mindre om sig själv och mer om hur hon uppförde sig i sällskap med andra och hur hon behandlade sina medmänniskor (Brumberg 1997).

I den borgerliga uppfostran betonades lydnaden inför auktoriteter som föräldrarna. Denna lydnad skulle inpräntas i barnen på en rad sätt. Barnen skulle lära sig att lyda men det handlade inte om någon ovillkorlig lydnad, utan om en lydnad som skulle uppstå $\mathrm{i}$ insikten att lydnad för sina föräldrar tillhörde en av de allra förnämsta dygderna. Professor Seved Ribbing menade i Våra barns fostran och vård från 1899, att genom uppfostran skall hos barnen inpräntas lydnaden som främsta egenskap. »Men denna skall icke komma såsom en den svages vikande för öfvermakten, den skall rent af under barnens tidigasteår såsammansmälta med deras innersta väsen och natur, att de icke kunna tänka sig något annat än att uppfylla föräldrarnes vilja.." ${ }^{16}$ Barnet måste inse

16 Ribbing, Seved (1899) Våra barns fostran och vårds. 177

Socialvetenskaplig tidskrift nr 1-2 • 2001 
att det bör följa sina föräldrars råd och regler för sitt eget bästa.

Förutom den praktiserade uppfostran i hemmet var barnboken ett sätt att sprida de önskvärda normerna. Häri framkom tydligt vilka egenskaper som inte var önskvärda. I sagan "Gossen som ej ville äta upp sin soppa" i den berömda barnboken Julbocken eller Pelle Snusk av Heinrich Hoffmann (1979), är budskapet till barn som tar kontrollen över sitt eget ätande och som bestämmer sig för att matvägra, tydligt. Gossen Kaspar som var så tjock, rund och sund bestämde sig en dag för att inte längre äta sin soppa. „Nej...bed mig ej- det icke sker,jag äter aldrig soppa mer", sa Kaspar och sedan gick det fort utför. Han magrade, blev tunn som en tråd och redan på den femte dagen var han död. Det matvägrande och olydiga barnet fick snabbt sitt obarmhärtiga straff. Lika ofta som barn bestraffades genom att få gå till sängs utan kvällsmat, tvingades de äta upp allt de tagit till sig på tallriken. Detta beteende från uppfostrarens sida, vilket fördömdes av samtida läkare, kan ha fått motsatt effekt och stimulerat till matvägran och uppror.

Flickors inre kontroll och matvägran har setts som mycket provocerande i den borgerliga kulturen eftersom måltiden har varit ett så centralt inslag. Enligt feministiska teorier är matvägran och självsvält en mer eller mindre öppen protest mot den samhälleliga norm som sätter upp riktlinjer för flickors levnadsramar. Den viktorianska flickan använde matvägran som ett av de få medel som det var accepterat att uttrycka sig igenom. Detta sätt var på något vis passande en ung flicka till skillnad från att uttrycka sig verbalt eller genom olämpligt uppförande som att kasta saker, skrika eller slå sönder porslin (Brumberg 1988).

\section{Den anorektiska kvinnligheten}

Det tycks finnas ett starkt behov av att kontrollera unga flickor som skulle kunna tolkas som ett förtryck av kvinnan. Kontrollformerna tar dock olika former utifrån olika sociala och kulturella sammanhang. Med Nancy Henleys terminologi skulle vi säga att betoningen på självkontroll i flickors uppfostran innebar att flickorna internaliserade kontrollen och på så sätt kontrollerade sig själva på en grundläggande nivå. Den yttre kontrollen fanns i form av mode och klädsel som förmedlades via bl.a. veckotidningar och reklam. Med hjälp av korsetten och den smala siluetten begränsades flickans kroppsliga rörlighet. Rörligheten i det sociala rummet begränsades med hjälp av moraliska pekpinnar i läkarböcker och uppfostringslitteratur i vilka författarna upplyste om var flickor inte borde befinna sig och vilka nöjen de inte borde befatta sig med. Under klorosens storhetstid anklagades till exempel flickor ur de högre samhällsklasserna för att själva dra på sig sjukdomen genom "...ett för tidigt deltagande i ett osunt sällskapsliv, nattvak, dans, för tidigt väckt könsdrift och ett därmed sammanhängande erotiskt fantasiliv, som söker sin näring i en osund romanläsning....1 ${ }^{17}$ Den moraliska undertonen var tydlig och syftade till att

17 Dumrath, O.H. (1915) Bleksot och blodbrist samt därmed besläktade sjukdomar. Wahlström och Widstrand Stockholm, s. 17. 
frånhålla flickorna nöjen i syfte att kontrollera dem och deras kärleksliv.

Det yttre förtrycket av flickans levnadsbetingelser från den tidiga borgerliga kulturen tycks ha ersatts med ett mindre synligt men ändå påtagligt inre förtryck. Brumberg (1997) ser en tydlig förändring från en yttre kontroll av karaktären och kroppen till en inre kontroll av utseendet $i$ undersökningen av de amerikanska flickorna från tidigt 1800-tal till i dag. Med det sena 1900-talets frihet att exponera sin kvinnlighet med hjälp av kroppen följde också ett tvång och en inre kontroll att hålla kroppen $\mathrm{i}$ trim och att vara vacker. Denna kroppsliga kontroll innebar naturligtvis kontroll av diet och träning då den nya kvinnan skulle vara smal, oformlig och pojklik i kroppen. För hundra år sedan kontrollerades kropparna med hjälpmedel utifrån, med korsetter och snörningar. I Hemläkaren beklagar sig läkaren Uhrström över det mode som i synnerhet kvinnor lät sig behärskas av: „Snörlif är likaledes en af modets fordringar och dertil en af de allra skadligaste. För att förskaffa sig en vacker figur och en smidig gestalt fäster man ofta ej afseende vid helsan. ${ }^{18}$ Hur mycket läkarna än predikade om snörlivets skadlighet tycktes kvinnorna inte vilja avstå från modet: „Om man än kunde uppräkna tusentals exempel på sjukdomar af hårdt åtdragna snörlif, såskulle dock anspråken på en smärt figur helt säkert bringa till tystnad våra råd. . ${ }^{19}$

18 Uhrström (1881), s.202. Uppslagsord Klädedrägt. Uhrström tycks dock se en ände på problemet: "Lyckligtvis äro snörlifven eller åtminstone missbruken af dem nu för tiden ej sà vanliga som fordom, och många flickor känna numera
Vi kan se att maten genom historien från medeltiden till tjugohundratalet har använts som ett medel för att utöva och uppnå kontroll. Det kan synas vara en paradox att flickan både kontrollerades av sina föräldrar genom att t.ex. inte få tillräckligt med mat för att hon skulle uppnå ett attraktivt kroppsideal, men också att hon själv använde matvägran som ett sätt att uppnå kontroll över tillvaron eller som en protest mot att hon inte hade någon kontroll. Likväl tycks det handla om att sätta gränser. Utifrån, genom uppfostran och samhälleliga normer, samt inifrån, genom flickans krav på sig själv och behov av kontroll. Anledningen till att just mat och ätande har utnyttjats som instrument både från flickan och hennes omgivning tyder på att just dessa komponenter har varit och är fortfarande oerhört laddade och effektfulla.

Frågan som bör ställas är om flickan är friare i dag än för hundra år sedan. En till synes större frihet från yttre krav begränsas i dag av de inre krav som flickan ställer på sig själv. Kulturen är en viktig faktor i skapandet av den ideala kvinnan och media är en viktig del av dagens kultur. Härigenom nås kvinnan av bilden av »kvinnan « och smalhetsidealet är en viktig beståndsdel i den förmedlade bilden. Jorun Solheim (1998) menar dock att det är inte först och främst smalhetsidealet som den anorektiska flickan vill efterlikna. Ett smalt kroppsideal är inte anledningen till att flickan svälter sin kropp. Det är snarare den moderna kvinnligheten som är anorektisk och som förnekar kvinno-

snörlifven endast till namnen. "s.205. Uppslagsord Klädedrägt.

19 Ibid. 
kroppen. Anorektikern uppvisar bara på ett extremt tydligt sätt det kvinnliga kollektiva idealet.

Medicinen har länge haft ensamrätt på tolkningen och definieringen avätstörningar. Orsakerna till både anorexia nervosa och bulimia nervosa har bestämtsinom det medicinska pardigmet och fortfarande behandlas flickornas tillstånd som individuella problem. Sökandet efter indivduella faktorer som kan orsaka sjukdomar som anorexia nervosa och bulimia nervosa, måste nyanseras. I en historisk belysning tycks problemet inte vara individuellt utan snarare kollektivt. Därför menar jag att vi bör blottlägga och granska det samhälle som ligger till grund för att unga kvinnor svälter sina kroppar. Vi bör också fundera över vilka konsekvenserna blir för de drabbade flickorna då vi behandlar ett kollektivt problem som om det vore enbart individuellt.

\section{Litteratur}

Bremer, Fredrika (1868) Fredrika Bremer: sjelfbiografiska anteckningar, bref och efterlemnade skrifter: jemte en teckning af hennes lefnad och personlighet. Utgiven av Charlotte Bremer Quiding, Örebro.

Brumberg, Joan Jacobs (1988) Fasting girls. The history of anorexia nervosa. Penguin books USA.

Brumberg, Joan Jacobs (1997) Body project. The intimate story of American girls. Random House New York.

Cederschiöld, F A (1852) Ett ord till Ömsinta Mödrar om Qvinnans Uppfostran. Stockholm.

Dumrath, O.H. (1915) Bleksot och blodbrist samt därmed besläktade sjukdomar. Wahlström och Widstrand Stockholm, s. 17.

Frykman, Jonas \& Löfgren, Orvar (1979) Den kultiverade människan. Gleerups förlag Malmö

Henley, Nancy (1977) The body politics. Power, sex, and nonverbal communication. Prentice-Hall, Inc. USA.

Hepworth, Julie (1999) The social construction of Anorexia nervosa. Safe Publications London.

Hildinger, Alf (1925) Moralisk fostran. En bok för föräldrar och andra ungdomens fostrare. Stockholm Bokförlaget Natur och Kultur.

Hoffman, Heinrich (1979) Julbocken eller Pelle Snusk. Lustiga historier och roliga bilder. Texten ur den sjätte svenska upplagan från 1913. Albert Bonniers Förlag Stockholm.

Johannisson, Karin (1997) Kroppens tunna skal. Norstedts förlag AB Stockholm.

Johannisson, Karin (1994) Den mörka kontinenten. Kvinnan, medicinen och fin-de siècle. Norstedts förlag AB Stockholm.

Kneipp, Sebastian (1894) Barnavård i friska och sjuka dagar. H. Geber Stockholm.

Lee, Sing (1996) "Reconsidering the status of anorexia nervosa as a western culture-bound syndrome", $i$ Social science and medicine, vol. 42, $\mathrm{nr} 1$.

Lindholm, Cajsa (1991) »Törnekrona- nu eller i evigheten? Helig och nutida anorexi i ett objekrelationsperspektiv«, i Psykisk hälsa nr 4.

Nasser, Mervat (1997) Culture and weight consciousness. Routledge London.

Ohrlander, Kajsa (1987) När barnet fick en kropp. Rapport 3, Högskolan för Lärarutbildning i Stockholm. Institutionen för pedagogik.

Prestjan, Anna (2000) „Humanistiska och samhällsvetenskapliga forskningsperspektiv på ätstörningar, exemplet anorexia» Opublicerad artikel, Örebro universitet.

Ribbing, Seved (1899) Vårabarns fostran och vård. Stockholm. 
Solheim, Jorun (1998), Den åpne kroppen. Om kjønnssymbolikk i moderne kultur. Pax forlag A/S Oslo.

Uhrström, Wilh. (1881) Hemläkaren. Populär ordbok $i$ sjukvård och helsolära enligt nutidens medicinska åsigter. Albert Bonniers Förlag Stockholm.

Wallgren , Madeleine (1995) Viktfixering, tvång eller frihet. Vingårdens förlag Hästveden. Vandereycken, Walter \& van Deth, Ron (1990) From. fasting saints to anorexic girls. The history of self-starvation. TheAthlone Press London

Winge, H \& Wallis, C (1885) Reformdrägten. En bok för qvinnor skrifven af qvinnor. Looström \&Komp. Stockholm.

\section{Summary \\ Brought up to self-starvation? External and internal control of the young girls body and character around 1900}

This article illuminates the problem of eating disorders among girls in a historical context. By discussing common denominators for the medieval "holy anorectics" and todayss self-starving young females, the author wants to question the common opinion that the eating disorders of our time are mainly caused by todayss emaciated ideal woman mediated by the media, popular culture and celebrities.

Self-starvation as a symptom is not a new phenomenon in the late twentieth century. As early as in the medieval period women used starvation of their bodies to attain selfcontrol. Then there was a search for spirituality rather than an endeavour to achieve a perfect body as today, but the body was still the site of the womanis protest. Theories about self-starvation from the late nineteenth century were created by medicine to explain why women suffered from eating disorders and why they developed diseases. The explanations were sought mainly within the medical paradigm, and it was not until the twentieth century that doctors seri- ously began to consider cultural or societal causes for mental diseases and psychological conditions such as eating disorders. Feminist writers and researchers claimed in the 1970s that eating disorders were caused by societal pressure on women and that self-starvation was the only means by which women could take control over at least some part of their lives. Refusing to eat was a strong protest against the patriarchal society and female subordination. Critically examining eating disorders and self-starvation from a cultural and historical perspective means questioning the society we have created and making the problem a collective one rather than putting the blame on the individual.

In this article one of the main aims is to examine the upbringing of girls around 1900. Are there some values and norms in Western bourgeois culture that can help us understand why young females suffer from anorexia nervosa, eating disorders and why they starve their bodies? The author makes an attempt to explain why factors such as 
food, body and gender still today are charged with symbolic meanings and why girls choose to use these factors to express their dissatisfaction.

In contemporary literature for educational purposes of the late nineteenth century the relevance of self-control of both body and character in a young girl is evident. Children and particularly girls were taught to be controlled in their behaviour toward other people, themselves and not least their eating. Regulation of the appetite was an important part of the female identity. But the use of control of the appetite was not only a privilege for the parents who could use food for both punishing and rewarding purposes. Young females themselves have also exercised internal control over their appetite. They have refused food to attain control of at least some part of their lives in a world where they have experienced solid pressure from their surroundings to be the perfect and subordinate girl, daughter and finally wife. The fact that girls have been controlled both externally and internally with the aid of appetite regulation seems to be a great paradox. The reason why food and eating have been used by both the girl and her parents indicates that these are the most charged symbols of them all. Still today girls use these symbols as an exaggerated expression of our collective ideals. 